\title{
Integrated Schools Movement: The Identification Of Character Education Values In Smp Piri 1 Yogyakarta
}

\author{
Bekti Chandra Sari ${ }^{1}$, Farida Hanum ${ }^{2}$ \\ Social Student Education, Post Graduate Program, Yogyakarta State University \\ bektychandra@gmail.com ${ }^{1}$,faridahanum@uny.ac.id ${ }^{2}$
}

\begin{abstract}
Providing character building for students is one of the school responsibilities. The program is included in the Presidential Regulation Number 87 Article 3 of 2017. Based on the regulation, both levels of high school, junior and senior, in Yogyakarta have already implemented character education in their teaching programs. This situation urged the researchers to conduct a study that aims to identify the characters of students in SMP PIRI 1 Yogyakarta. The research is a descriptive study with quantitative approach. The data collection techniques used was questionnaires and documentation. The subject of the study was students of SMP PIRI 1 Yogyakarta, determined through simple random sampling technique. The researchers used a quantitative descriptive analysis technique to analyze the data, which is described in the form of a percentage. After calculating the percentage, a character identification category for students in PIRI 1 Yogyakarta was determined. The results showed that as many as $16.4 \%$ of the students' characters are included in the category of "Very Low", 19.2\% are included in the category of "Low", $42.3 \%$ included in the category of "Moderate" , 14.2\% included in the "High" category, and $7.88 \%$ included in the "Very High" category. Based on these results, it can be identified that the character of students has an average value of 2.337 or included in the category of "Moderate".
\end{abstract}

Key words. character, identification

\section{Introduction}

Character is needed by every human being, especially students to foster a better and more civilized life. Character is closely related to one's personality. This means that an individual can be called as a person of character when their behavior is in accordance with ethics or moral rules [1]. One of the parties required to implement a character building program is the educational institutes. Schools should instill character education to students as early as possible. The implementation of character education in the school environment is also issued in the Presidential Regulation Number 87 of 2017 on the Strengthening of Character Education. Character education have 18 values. The program can be done in an integrated manner whether in intra-curricular activities; co-curricular; and extra-curricular on the education unit of formal schools. Following up on the Presidential Regulation, all middle and high schools in the city of Yogyakarta integrated the character education in every activity at the school. The Yogyakarta City Education Office revealed that as many as 138 middle and high schools in the city of Yogyakarta have integrated the program in their activities. Character education is an inculcation of character values to school members which includes components of knowledge, awareness or willingness, and actions to implement these values [2]. 
[3] One way to build the nation character is through the world of education. However, although character education has been integrated in various ways, in reality there are still violations committed by students. These violations not only occur in the school environment, but also outside the school environment. Based on the schools' complaints to the Yogyakarta City Education Office, it was explained that the violations often committed by students were related to discipline and responsibility. The data from the Yogyakarta Police and Criminal Investigation Unit in 2012 until 2017 are proofs that many students still could not be capable enough to meet their responsibilities. This illustrates that students have diverse characters. The diversity of characters comes from the habits of the family and community environment. Therefore, to form good character and minimize the occurrence of violations committed by students, it is very necessary to strengthen character education in the school environment.

In 2012 there were 51 students found guilty by the law because they committed violations related to criminal acts. In 2013, there was an increase in the number of perpetrators, i.e. 55 students. In 2014, the number got decreased to 34 students. However, there is a significant escalation in the number of criminal acts committed by students in 2015 , reaching up to 66 students. The number is the same as what happened in 2016. In 2017 the number increased slightly to 71 students. The types of violations related to criminal acts that are often committed by students are theft, persecution, and beating. [4] Essentially the crime is a reflection of a person's personality which is formed and built from the experience through which they were born. To improve the various experiences they went through from birth, it is necessary to strengthen character education in schools. Character education in schools is a program used to improve the characters of students. The application of character education is very urgent to be internalized to students, with the hope that in the future the young generation of Indonesia will have a strong morality and character as national identity [5].

One of the schools in the city of Yogyakarta that has instilled the character education strengthening program is SMP PIRI 1 Yogyakarta. The program is carried out by integrating it into the subjects taught in school. In addition, the program is also integrated through extracurricular activities and other activities. Even though schools have intensified the integration of character education, there are still violations committed by students. Violations committed by students in Yogyakarta PIRI 1 Junior High School are very diverse. One example of violations that fall into the category of crime also exists. A ninth grade student once was found out carrying a sharp weapon in the form of a long sword. The case occurred in 2017. Upon this incident, the school handed it over to the Yogyakarta County Police. [6] Character education can be defined as any effort made by the teachers, which can give positive influence to the students and their characters. Seeing various cases of violations and even criminal acts committed by unscrupulous students in SMP PIRI 1 Yogyakarta, the researchers were interested in identifying the success of inculcating character values in SMP PIRI 1 Yogyakarta.

\section{Method}

The research is a quantitative study that examines and identifies the success of inculcating the values of students' characters in SMP PIRI 1 Yogyakarta. The variable in this study is the identification of the success of students' character values. Character values measured in this study include religiosity, honesty, tolerance, discipline, hardworking, creativity, independence, democracy, curiosity, spirit of nationalism, patriotism, achievement appreciations, friendliness, 
love of peace, reading fondness, environment awareness, social awareness, and responsibility values. The study population was 123 students of SMP PIRI 1 Yogyakarta. Of the 123 students, samples were taken using the Slovin formula as follows. Using the formula above, when the population is 123 people with the error tolerance limit of $10 \%$, then it is safe to say that the number of samples obtained is 55 students. Sampling in each class was done randomly.

The techniques of data collection needed in this study were through questionnaires and documentation. Data collection instruments consisted of questionnaire sheets and documentation. The researchers used descriptive statistics in analyzing the data. In this study, descriptive statistical techniques were used to describe or identify the character of students in SMP PIRI 1 Yogyakarta. Presentation of statistical data in this study is in the form of a percentage calculation. Descriptive analysis was used to describe the data by determining the central tendency which includes the calculation of mean (Mean), median (Me), mode (Mo), highest score (Max), lowest score (Min), and standard deviation (SD).

\section{Result And Discussion}

This research was conducted at SMP PIRI 1 Yogyakarta. The purpose of this study was to determine and identify the character of students in SMP PIRI 1 Yogyakarta. Determination of identification is calculated based on the average results obtained from respondents, which are further categorized into five categories, namely very high, high, moderate / medium, low, and very low.

The identification of students' characters is determined by several indicators of assessment, including: religiosity, honesty, tolerance, discipline, hardworking, creativity, independence, democracy, curiosity, spirit of nationalism, patriotism, achievement appreciations, friendliness, love of peace, reading fondness, environment awareness, social awareness, and responsibility values. The character identification of students in SMP PIRI 1 Yogyakarta is as follows.

Table 1. Identification of Students' Characters

\begin{tabular}{ccccccc}
\hline $\begin{array}{c}\text { Variable } \\
\text { Indicator }\end{array}$ & Very Low & Low & Moderate & High & Very High & $\begin{array}{c}\text { Mean } \\
\text { Score }\end{array}$ \\
\hline \multirow{2}{*}{ Religiosity } & 3 & 10 & 16 & 17 & 9 & 2.70 \\
& $(5.5 \%)$ & $(18.2 \%)$ & $(29.1 \%)$ & $(30.9 \%)$ & $(16.4 \%)$ & \\
Honesty & 6 & 15 & 19 & 11 & 4 & 2.44 \\
& $(10.9 \%)$ & $(27.3 \%)$ & $(34.5 \%)$ & $(20 \%)$ & $(7.3 \%)$ & \\
Tolerance & 3 & 9 & 24 & 15 & 4 & 2.55 \\
& $(5.5 \%)$ & $(16.4 \%)$ & $(43.6 \%)$ & $(27.3 \%)$ & $(7.3 \%)$ & \\
Discipline & 19 & 15 & 20 & 1 & 0 & 2.01 \\
Hardworking & $(34.5 \%)$ & $(27.3 \%)$ & $(36.4 \%)$ & $(1.8 \%)$ & 0 & \\
& 2 & 1 & 35 & 8 & 9 & 2.65 \\
Creativity & $(3.6 \%)$ & $(1.8 \%)$ & $(63.6 \%)$ & $(14.5 \%)$ & $(16.4 \%)$ & \\
& 3 & 5 & 38 & 7 & 2 & 2.47 \\
Independence & $(5.5 \%)$ & $(9.1 \%)$ & $(69.1 \%)$ & $(12.7 \%)$ & $(3.6 \%)$ & \\
& $(12.7 \%)$ & $(10.9 \%)$ & $(54.5 \%)$ & $(16.4 \%)$ & $(5.5 \%)$ & 2.49 \\
Democracy & 5 & 15 & 21 & 8 & 6 & 2.27 \\
& $(9.1 \%)$ & $(27.3 \%)$ & $(38.2 \%)$ & $(14.5 \%)$ & $(10.9 \%)$ & \\
Curiosity & 1 & 6 & 39 & 6 & 3 & 2.48 \\
\hline
\end{tabular}




\begin{tabular}{|c|c|c|c|c|c|c|}
\hline $\begin{array}{c}\text { Spirit of } \\
\text { Nationalism }\end{array}$ & $\begin{array}{c}8 \\
(14.5 \%)\end{array}$ & $\begin{array}{c}19 \\
(34.5 \%)\end{array}$ & $\begin{array}{c}21 \\
(38.2 \%)\end{array}$ & $\begin{array}{c}3 \\
(5.5 \%)\end{array}$ & $\begin{array}{c}4 \\
(7.3 \%)\end{array}$ & 1.75 \\
\hline Patriotism & $\begin{array}{c}5 \\
(9.1 \%)\end{array}$ & $\begin{array}{c}8 \\
(14.5 \%)\end{array}$ & $\begin{array}{c}22 \\
(40 \%)\end{array}$ & $\begin{array}{c}13 \\
(23.6 \%)\end{array}$ & $\begin{array}{c}7 \\
(12.7 \%)\end{array}$ & 1.80 \\
\hline $\begin{array}{l}\text { Achievement } \\
\text { Appreciations }\end{array}$ & $\begin{array}{c}3 \\
(5.5 \%)\end{array}$ & $\begin{array}{c}9 \\
(16.4 \%)\end{array}$ & $\begin{array}{c}19 \\
(34.5 \%)\end{array}$ & $\begin{array}{c}16 \\
(29.1 \%)\end{array}$ & $\begin{array}{c}8 \\
(14.5 \%)\end{array}$ & 2.70 \\
\hline Friendliness & $\begin{array}{c}1 \\
(1.8 \%)\end{array}$ & $\begin{array}{c}12 \\
(21.8 \%)\end{array}$ & $\begin{array}{c}20 \\
(36.4 \%)\end{array}$ & $\begin{array}{c}11 \\
(20 \%)\end{array}$ & $\begin{array}{c}11 \\
(20 \%)\end{array}$ & 2.44 \\
\hline Love of Peace & $\begin{array}{c}24 \\
(43.6 \%)\end{array}$ & $\begin{array}{c}12 \\
(21.8 \%)\end{array}$ & $\begin{array}{c}11 \\
(20 \%)\end{array}$ & $\begin{array}{c}5 \\
(9.1 \%)\end{array}$ & $\begin{array}{c}3 \\
(5.5 \%)\end{array}$ & 2.55 \\
\hline $\begin{array}{l}\text { Reading } \\
\text { fondness }\end{array}$ & $\begin{array}{c}9 \\
(16.4 \%)\end{array}$ & $\begin{array}{c}3 \\
(5.5 \%)\end{array}$ & $\begin{array}{c}41 \\
(74.5 \%)\end{array}$ & $\begin{array}{c}1 \\
(1.8 \%)\end{array}$ & $\begin{array}{c}1 \\
(1.8 \%)\end{array}$ & 2.01 \\
\hline $\begin{array}{l}\text { Environment } \\
\text { Awareness }\end{array}$ & $\begin{array}{c}4 \\
(7.3 \%)\end{array}$ & $\begin{array}{c}11 \\
(20 \%)\end{array}$ & $\begin{array}{c}27 \\
(49.1 \%)\end{array}$ & $\begin{array}{c}9 \\
(16.4 \%)\end{array}$ & $\begin{array}{c}4 \\
(7.3 \%)\end{array}$ & 2.65 \\
\hline $\begin{array}{c}\text { Social } \\
\text { Awareness }\end{array}$ & $\begin{array}{c}34 \\
(61.8 \%)\end{array}$ & $\begin{array}{c}12 \\
(21.8 \%)\end{array}$ & $\begin{array}{c}8 \\
(14.5 \%)\end{array}$ & $\begin{array}{c}1 \\
(1.8 \%)\end{array}$ & 0 & 2.47 \\
\hline Responsibility & $\begin{array}{c}25 \\
(45.5 \%)\end{array}$ & $\begin{array}{c}22 \\
(40 \%)\end{array}$ & $\begin{array}{c}8 \\
(14.5 \%)\end{array}$ & 0 & 0 & 2.49 \\
\hline Total & $\begin{array}{c}162 \\
(16.4 \%)\end{array}$ & $\begin{array}{c}190 \\
(19.2 \%)\end{array}$ & $\begin{array}{c}419 \\
(42.3 \%)\end{array}$ & $\begin{array}{c}141 \\
(14.2 \%)\end{array}$ & $\begin{array}{c}78 \\
(7.88 \%)\end{array}$ & 2.37 \\
\hline
\end{tabular}

The table above shows that the respondents' ratings of the characters existing in each of them are as follows; $16.4 \%$ of respondents fall into the "Very Low" category, $19.2 \%$ are included in the "Low" category, $42.3 \%$ are included in the "Moderate" category, as many as $14.2 \%$ are included in the "High" category, and as much as $7.88 \%$ are included in the "Very High" category. Based on these results, the characters of students in SMP PIRI 1 Yogyakarta in general is not good, this is indicated by the assessment of respondents who are mostly included in the category of "Moderate". The students' characters based on each of the assessment indicator are explained in more detail as follows.

\subsection{The Indicator of Religiosity}

Table 2. The Indicator of Religiosity

\begin{tabular}{cccc}
\hline Indicator & Sub-indicator & Mean & Category \\
\hline \multirow{3}{*}{ Religiosity } & Persevering praying & 2.66 & Moderate \\
& Attentive worship & 2.76 & Moderate \\
& practicing & & Moderate \\
\hline & Mean & 2.71 &
\end{tabular}

The religiosity level of students in SMP PIRI 1 Yogyakarta is not high because it does not meet the criteria from the theory that researchers use. Based on the theory, a person is said to have a high level of religiosity if, [7] one's faith and devotion are reflected in the habit of praying when they are about to and after doing activities, committed to their religion rules, diligently recite the Quran, and doing good deeds that are beneficial to the world and the hereafter. 


\subsection{The Indicator of Honesty}

Table 3. The Indicator of Honesty

\begin{tabular}{cccc}
\hline Indicator & Sub-indicator & Mean & Category \\
\hline \multirow{2}{*}{ Honesty } & Truthful & 2.49 & Moderate \\
& Well-behaved & 2.41 & Moderate \\
\hline & Mean & 2.45 & Moderate \\
\hline & Source: 2018 Processed Data
\end{tabular}

The level of honesty of SMP PIRI 1 Yogyakarta students is not high because it is not in accordance with the criteria from the theory that researchers use. Based on the theory, a person is said to have a good level of honesty when their actions are addressed as efforts to make themselves a person who can be trusted by what they say and do [8].

\subsection{The Indicator of Tolerance}

Table 4. The Indicator of Tolerance

\begin{tabular}{lccc}
\hline Indicator & Sub-indicator & Mean & Category \\
\hline \multirow{2}{*}{ Tolerance } & Respect towards other religions & 2.53 & Moderate \\
& Respect towards others' opinions & 2.50 & Moderate \\
\hline & Mean & 2.56 & Moderate \\
\hline
\end{tabular}

Source: 2018 Processed Data

The level of tolerance of students in SMP PIRI 1 Yogyakarta is not high because it is not in accordance with the criteria from the theory that researchers use. Based on the theory, tolerance is an attitude and / or action that represent respect towards diversity in religion, ethnicity, race, opinions, attitudes, and actions of others who are different from theirs [9].

\subsection{The Indicator of Discipline}

Table 5. The Indicator of Discipline

\begin{tabular}{|c|c|c|c|}
\hline Indicator & Sub-indicator & Mean & Category \\
\hline \multirow{2}{*}{ Discipline } & Diligent & 1.87 & Very Low \\
\hline & Obedient & 2.07 & Low \\
\hline \multicolumn{2}{|c|}{ Mean } & 1.97 & Low \\
\hline
\end{tabular}

The discipline level of students in SMP PIRI 1 Yogyakarta is not high because it does not meet the criteria from the theory that researchers use. The theory explains that discipline is reflected in the way someone does things in an orderly manner, utilizes time with positive activities, studies regularly, and always takes full of responsibilities of the things they do [7].

\subsection{The Indicator of Hardworking}

Table 6. The Indicator of Hardworking

\begin{tabular}{cccc}
\hline Indicator & Sub-indicator & Mean & Category \\
\hline \multirow{2}{*}{ Hardworking } & Giving their best in doing assignments & 2.61 & Moderate \\
& Tenacious & 2.69 & Moderate \\
\hline & Mean & 2.65 & Moderate \\
\hline
\end{tabular}

Source: 2018 Processed Data 
The hardworking level of students in SMP PIRI 1 Yogyakarta is not high because it does not meet the criteria from the theory that researchers use. The theory explains that hardworking attitude can be reflected from how often a person help their parents, teachers, friends, and others; try to learn independently and in groups; is accustomed to doing homework and school assignments [7].

\subsection{The Indicator of Creativity}

Table 7. The Indicator of Creativity

\begin{tabular}{cccc}
\hline Indicator & Sub-indicator & Mean & Category \\
\hline \multirow{2}{*}{ Creativity } & Having different way of thinking & 2.53 & Moderate \\
& Having original ideas & 2.36 & Moderate \\
\hline & Mean & 2.44 & Moderate \\
\hline
\end{tabular}

Source: 2018 Processed Data

The creativity level of students in SMP PIRI 1 Yogyakarta is not high because it does not meet the criteria from the theory that researchers use. The theory [7] elaborates that a person is said to be creative when they are able to make use of their free time by doing useful activities and accustomed to creating new ideas.

\subsection{The Indicator of Independence}

Table 8. The Indicator of Independence

\begin{tabular}{cccc}
\hline Indicator & Sub-indicator & Mean & Category \\
\hline \multirow{2}{*}{ Independence } & Not dependent to others & 2.48 & Moderate \\
& Able to solve problems on their own & 2.49 & Moderate \\
\hline & Mean & 2.48 & Moderate \\
\hline \multicolumn{3}{c}{ Source: 2018 Processed Data }
\end{tabular}

The independence level of students in SMP PIRI 1 Yogyakarta is not high because it does not meet the criteria from the theory that researchers use. The theory states that the characteristic of an independent person is their ability to act with their own initiative and capability [7].

\subsection{The Indicator of Democracy}

Table 9. The Indicator of Democracy

\begin{tabular}{cccc}
\hline Indicator & Sub-indicator & Mean & Category \\
\hline \multirow{2}{*}{ Democracy } & Actively participating in class discussion & 2.53 & Moderate \\
& Actively participating in school activities & 2.22 & Moderate \\
\hline Mean & 2.37 & Moderate \\
\hline
\end{tabular}

Source: 2018 Processed Data

The democracy level of students in SMP PIRI 1 Yogyakarta is not high because it does not meet the criteria from the theory that researchers use. Based on the theory, the way to identify whether someone has a democratic attitude or not is seen from how they cooperate with others; listen to others' advice; are not devious and arrogant; and are accustomed to obeying the rules [7]. 


\subsection{The Indicator of Curiosity}

Table 10. The Indicator of Curiosity

\begin{tabular}{cccc}
\hline Indicator & Sub-indicator & Mean & Category \\
\hline \multirow{2}{*}{ Curiosity } & Open to new things & 2.45 & Moderate \\
& Actively ask questions in class & 2.58 & Moderate \\
\hline \multicolumn{3}{c}{2.51} & Moderate \\
\hline \multicolumn{3}{c}{ Source: 2018 Processed Data }
\end{tabular}

The curiosity level of students in SMP PIRI 1 Yogyakarta is not high because it does not meet the criteria from the theory that researchers use. Based on the theory, a person is said to have high level of curiosity when they seek to find out about the things they are not familiar with more deeply and broadly with the help of their background knowledge [9].

\subsection{The Indicator of Spirit of Nationalism}

Table 11. The Indicator of Spirit of Nationalism

\begin{tabular}{cccc}
\hline Indicator & Sub-indicator & Mean & Category \\
\hline Spirit of & Attending the flag ceremony & 2.06 & Low \\
Nationalism & Prioritizing national interests & 2.71 & Moderate \\
\hline \multicolumn{3}{c}{2.38} & Moderate \\
\hline & Mean & Source: 2018 Processed Data
\end{tabular}

The spirit of nationalism level of students in SMP PIRI 1 Yogyakarta is not high because it does not meet the criteria from the theory that researchers use. Based on the theory, a person's spirit of nationalism is said to be high when they devote themselves to the nation and country as well as taking full responsibility of their people [10].

\subsection{The Indicator of Patriotism}

Table 12. The Indicator of Patriotism

\begin{tabular}{cccc}
\hline Indicator & Sub-indicator & Mean & Category \\
Patriotism & Natural environment awareness & 2.55 & Moderate \\
& Social environment awareness & 2.62 & Moderate \\
& Mean & 2.58 & Moderate \\
\hline
\end{tabular}

Source: 2018 Processed Data

The patriotism level of students in SMP PIRI 1 Yogyakarta is not high because it does not meet the criteria from the theory that researchers use. Based on the theory, a person is said to have high level of patriotism when everything they think and do always reflects acts of loyalty, care, and big respect for the nation, physical environment, social, cultural, economic, and the national politics [9].

\subsection{The Indicator of Achievement Appreciation}

Table 13. The Indicator of Achievement Appreciation

\begin{tabular}{cccc}
\multicolumn{4}{c}{ Table 13. The Indicator of Achievement Appreciation } \\
\hline Indicator & Sub-indicator & Mean & Category \\
\hline Achievement & Appreciating others' success & 2.45 & Moderate \\
Appreciation & Not comparing others' achievements & 2.76 & Moderate \\
\hline & Mean & 2.60 & Moderate \\
\hline
\end{tabular}

Source: 2018 Processed Data 
The achievement appreciation level of students in SMP PIRI 1 Yogyakarta is not high because it does not meet the criteria from the theory that researchers use. The theory [7] states that the act of appreciating others can be identified through the way a person behaves and respects others' efforts; does not underestimate others' efforts and achievements.

\subsection{The Indicator of Friendliness}

Table 14. The Indicator of Friendliness

\begin{tabular}{cccc}
\hline Indicator & Sub-indicator & Mean & Category \\
\hline \multirow{2}{*}{ Friendliness } & Sociable & 2.64 & Moderate \\
& Easy going & 2.71 & Moderate \\
\hline & Mean & 2.67 & Moderate \\
\hline \multicolumn{3}{c}{ Source: 2018 Processed Data }
\end{tabular}

The friendliness level of students in SMP PIRI 1 Yogyakarta is not high because it does not meet the criteria from the theory that researchers use. Based on the theory, a person is said to be friendly when they are able to befriend anyone without being biased [11].

\subsection{The Indicator of Love of Peace}

Table 15. The Indicator of Love of Peace

\begin{tabular}{cccc}
\hline Indicator & Sub-indicator & Mean & Category \\
\hline Love of & Not easily provoked & 1.93 & Low \\
Peace & Not hurting others & 2.03 & Low \\
\hline & Mean & 1.98 & Low \\
\hline & Source: 2018 Processed Data
\end{tabular}

The love of peace level of students in SMP PIRI 1 Yogyakarta is not high because it does not meet the criteria from the theory that researchers use. Based on the theory, a person is said to love peace when their attitudes, words, and actions can make other people comfortable with their presence and feel happy [9].

\subsection{The Indicator of Reading fondness}

Table 16. The Indicator of Reading fondness

\begin{tabular}{cccc}
\hline Indicator & Sub-indicator & Mean & Category \\
\hline $\begin{array}{c}\text { Reading } \\
\text { fondness }\end{array}$ & $\begin{array}{c}\text { Reading at any time } \\
\text { Reading Social Science } \\
\text { books }\end{array}$ & 2.08 & $\begin{array}{c}\text { Low } \\
\text { Moderate }\end{array}$ \\
\hline & Mean & 2.45 & Moderate \\
\hline
\end{tabular}

Source: 2018 Processed Data

The reading fondness level of students in SMP PIRI 1 Yogyakarta is not high because it does not meet the criteria from the theory that researchers use. Based on the theory, a person is said to be fond of reading when they intentionally take time or make use of their free time to read various literature providing positive influence for them [9]. 


\subsection{The Indicator of Environment Awareness}

Table 17. The Indicator of Environment Awareness

\begin{tabular}{|c|c|c|c|}
\hline Indicator & Sub-indicator & Mean & Category \\
\hline Environment & Not littering & 2.61 & Moderate \\
\hline Awareness & Keeping the classroom clean & 2.35 & Moderate \\
\hline & Mean & 2.48 & Moderate \\
\hline
\end{tabular}

The environment awareness level of students in SMP PIRI 1 Yogyakarta is not high because it does not meet the criteria from the theory that researchers use. The theory [8] states that the attitudes or actions showing concerns towards the environment are when a person tries to prevent environmental damage and fix the damage that has already occurred to create a better environmental situation.

\subsection{The Indicator of Social Awareness}

Table 18. The Indicator of Social Awareness

\begin{tabular}{cccc}
\hline Indicator & Sub-indicator & Mean & Category \\
\hline Social & Helpful & 1.65 & Very Low \\
Awareness & Sympathetic & 1.85 & Very Low \\
\hline & Mean & 1.75 & Very Low \\
\hline
\end{tabular}

Source: 2018 Processed Data

The social awareness level of students in SMP PIRI 1 Yogyakarta is not high because it does not meet the criteria from the theory that researchers use. Based on the theory, one of the ways to identify whether a person has a high sense of social awareness or not is by implementing the values of togetherness in social life [7].

\subsection{The Indicator of Responsibility}

Table 19. The Indicator of Responsibility

\begin{tabular}{cccc}
\hline Indicator & Sub-indicator & Mean & Category \\
\hline \multirow{2}{*}{ Responsibility } & Trustworthy & 1.88 & Very Low \\
& Wise & 1.72 & Very Low \\
\hline \multicolumn{2}{c}{ Mean } & 1.80 & Very Low \\
\hline \multicolumn{2}{c}{ Source: 2018 Processed Data }
\end{tabular}

The responsibility level of students in SMP PIRI 1 Yogyakarta is not high because it does not meet the criteria from the theory that researchers use. The theory [7] states that the attitude of being responsible can be identified through a person's action in acknowledging the rules applied in the societ, whether they are being obedient or not so that they can be the role model for the society and trusted by others.

\section{Conclusion}

Out of all the indicators examined, there are twelve indicators included in the "moderate" category, one indicator included in the "low" category, two indicators included in the "very 
low" category, two indicators included in the "low and moderate" category, and one indicator included in the "very low and low" category. The twelve indicators included in the "moderate" category are religiosity, honesty, tolerance, hardworking, creativity, independence, democracy, curiosity, and friendliness values. The indicator included in the "low" category is the love of peace value. Two indicators that are included in the "very low" category are social awareness and responsibility values. Two indicators are included in the category of "low and medium", namely the spirit of nationalism and reading fondness values. The indicator included in the "very low and low" category is the discipline value.

From the results above, it is clearly seen that the character identification of students in SMP PIRI 1 Yogyakarta is in the level of "moderate" or has an average of 2.37. "Moderate" level can be interpreted that the character of students in SMP PIRI 1 Yogyakarta is not optimal. The character value that gets the lowest average score is the spirit of nationalism with only at the average number of 1.75. The character value that gets the highest average score is religiosity and achievements appreciations with the number of mean reaching up to 2.70 . There are still some character values that have low scores. This is the reason why many students in SMP PIRI 1 Yogyakarta committed such delinquencies. The reason of those various acts of rules violations is because students do not apply the character values that have been taught at school. This situation should be a reflection reference for the school, especially teachers, to emphasize and instill character education in every school activity.

\section{References}

[1] Mulyasa. (2013). Manajamen Pendidikan Karakter. Jakarta: Bumi Aksara

[2] Sudarsono, Sudrajat \& Wibowo, S. (2016). Implementasi Pendidikan Karakter di SMP Negeri 2 Klaten dan MTS Wahid Hasyim Yogyakarta, JIPSINDO, 1, (3), 1

[3] Saliman, Widiastuti, A.\& Wulandari, T. (2013). Persepsi dan Sikap Mahasiswa terhadap Pendidikan Karakter di Prodi Pendidikan IPS UNY,SOCIA, 10,(2), 139-146

[4] Saliman. (2015). Bentuk-Bentuk Kenakalan Siswa SMP di Kota Yogyakarta, JIPSINDO, 2, (2), 179

[5] Wulandari, T. (2017). Implementasi Pendidikan Karakter Berbasis Multikultural di SMK Negeri 2 Mataram, SOCIA, 14, (2), 1

[6] Saliman \& Wahyuni, Y.S. (2018). Pendidikan Karakter dalam Perspektif Budaya Bangsa. Yogyakarta: UNY Press

[7] Majid, A. \& Andayani, D. (2013). Pendidikan Karakter Perspektif Islam. Bandung: PT Remaja Rosdakarya

[8] Wiyani, Novan Ardi. (2013). Konsep, Praktik \& Strategi Membumikan Pendidikan Karakter di SD. Yogyakarta: Ar-Ruzz Media

[9] Wibowo, A. (2012). Pendidikan Karakter Strategi Membangun Karakter Bangsa Berkepribadian. Yogyakarta: Pustaka Pelajar

[10] Amri, S. Jauhari, A. \& Elisah, T. (2011). Implementasi Pendidikan Karakter dalam Pembelajaran. Jakarta: PT. Prestasi Pustakaraya

[11] Wiyani, Novan Ardi. (2013). Konsep, Praktik \& Strategi Membumikan Pendidikan Karakter di SD. Yogyakarta: Ar-Ruzz Media 